\title{
Parabirojimia multinucleata spec. nov. and Anteholosticha scutellum (Cohn, 1866) Berger, 2003, marine ciliates (Ciliophora, Hypotrichida) from tropical waters in southern China, with notes on their small-subunit rRNA gene sequences
}

\author{
Xiangrui Chen, ${ }^{1}$ Shan Gao, ${ }^{1}$ Weibo Song, ${ }^{1}$ Khaled A. S. Al-Rasheid, ${ }^{2}$ \\ Alan Warren, ${ }^{3}$ Jun Gong ${ }^{3,4}$ and Xiaofeng Lin $^{4}$ \\ ${ }^{1}$ Laboratory of Protozoology, Ocean University of China, Qingdao 266003, PR China \\ ${ }^{2}$ Zoology Department, King Saud University, Riyadh 11451, Saudi Arabia \\ ${ }^{3}$ Department of Zoology, Natural History Museum, London SW7 5BD, UK \\ ${ }^{4}$ Laboratory of Protozoology, College of Life Science, South China Normal University, Guangzhou \\ 510631, PR China
}

Correspondence

Weibo Song

wsong@ouc.edu.cn

\section{INTRODUCTION}

The hypotrichs are a species-rich and morphologically diverse group of ciliates. Many marine hypotrichous species have not been adequately investigated, and their identification remains problematic. Much of this confusion exists because earlier studies provided descriptions only of morphology, without accurate information on the infraciliature and without adequate morphometric data, leaving the validity of many species uncertain. A typical example of such a species is Anteholosticha scutellum (Cohn, 1866) Berger, 2003. In recent years, this situation has improved, with the routine application of silver impregnation methods when describing new taxa (Borror \& Wicklow, 1983; Berger, 2004, 2006; Hu et al., 2002; Li et al., 2008; Lin

Abbreviations: AZM, adoral zone of membranelles; BI, Bayesian inference; ML, maximum likelihood; MP, maximum parsimony; SSU, small subunit.

The GenBank/EMBL/DDBJ accession numbers for the SSU rRNA gene sequences of Parabirojimia multinucleata and Anteholosticha scutellum are FJ156104 and FJ156105. et al., 2008; Lynn \& Small, 2002; Shao et al., 2008a, b; Hu, 2008).

The genus Parabirojimia was established by $\mathrm{Hu}$ et al. (2002) and is characterized as follows: adoral zone of membranelles (AZM) bipartite; frontal cirri clearly differentiated; buccal cirrus (cirri) and transverse cirri present; frontoterminal and caudal cirri absent; midventral complex composed of midventral pairs and one or more midventral rows at posterior end of complex; one left and two or more right marginal rows which derive from individual anlagen within each parental row; transverse cirri originate within frontal-midventral-transverse cirri anlagen and from part of the right marginal cirri anlagen. Parabirojimia similis $\mathrm{Hu}$ et al., 2002 is the only described species of this genus.

In the spring of 2008, during a survey of the ciliate fauna in coastal waters of Daya Bay in southern China, we isolated two hypotrichs. One appeared to represent a novel species of the genus Parabirojimia, whereas the other was Anteholosticha scutellum, a poorly known form which was originally described by Cohn (1866) as Oxytricha scutellum. 
The morphology and infraciliature of these two species together with their small-subunit (SSU) rRNA gene sequences are described here.

\section{METHODS}

The two hypotrichs were collected on 18 March 2008 from Daya Bay $\left(22^{\circ} 36^{\prime} 03^{\prime \prime} \mathrm{N} 114^{\circ} 32^{\prime} 46^{\prime \prime} \mathrm{E}\right)$, on the South China Sea coast of southern China. The water temperature was about $25{ }^{\circ} \mathrm{C}$, salinity about $28 \%$ and $\mathrm{pH}$ about 7.8. Parabirojimia multinucleata was collected from the surface of a sea squirt species (Pyura sp.) in musselculturing waters. Anteholosticha scutellum was collected from a sandy beach by sampling the upper $15 \mathrm{~cm}$ layer of sand together with water from the site and maintaining as raw cultures for 1 week at room temperature.

Live cells were observed with differential interference contrast microscopy and their infraciliature was revealed using the protargol impregnation method according to Wilbert (1975). Living individuals were examined and measured at $\times 1000$ magnification; counts, measurements and drawings of stained specimens were performed at $\times 1250$ magnification with the aid of a camera lucida (Lin et al., 2007). Terminology is mainly according to Corliss (1979) and Berger (2006).

Genomic DNA extraction, PCR amplification and SSU rRNA gene cloning and sequencing were performed according to Gong et al. (2007) and Yi et al. (2008). The sequence of P. similis (GenBank accession no. DQ503584) was used for comparison with P. multinucleata. The nucleotide sequences of four other Anteholosticha species were used for comparative purposes: Anteholosticha manca (GenBank accession no. DQ503578), Anteholosticha multistilata (AJ277876), Anteholosticha sp1-QD-07060701 (FJ775713) and Anteholosticha sp2-QD-04082401 (EF123707). Other sequences used in this study were obtained from the NCBI/GenBank database. Phylogenetic trees were constructed according to the methods reported by Gao et al. (2008).

Briefly, the program MRMODELTEST version 2 (Nylander, 2004) selected GTR + I+G under the AIC as the best model, which was then used for Bayesian and maximum-likelihood (ML) analysis. A Bayesian inference (BI) was performed with MrBayes 3.1.2 (Ronquist \& Huelsenbeck, 2003) and the program was run for 1000000 generations with a sample frequency of 100 and a burn-in of 2500. An ML tree was constructed with the PhyML program version 2.4.4 (Guindon \& Gascuel, 2003) with 1000 bootstrap replicates. A maximum-parsimony (MP) tree was produced with PAUP ${ }^{*}$ 4.0b10 (Swofford, 2002) by bootstrapping with 1000 replicates.

\section{RESULTS}

\section{Parabirojimia multinucleata spec. nov. (Figs 1 and 2; Tables 1 and 2)}

Diagnosis. Marine Parabirojimia, 150-350 × 30-60 $\mu \mathrm{m}$ in vivo; body outline elongate elliptical; AZM bipartite with 46-60 membranelles in total; five right and one left marginal rows; three frontal, one buccal and six to 11 transverse cirri; midventral complex composed of about five cirral pairs and one long ventral row of 44-69 cirri; three dorsal kineties; about 50 macronuclear nodules.

Etymology. This species has about 50 macronuclear nodules; therefore, its name recalls this feature: multi(many), nucleate.

Type locality. Mussel-culturing waters in Daya Bay $\left(22^{\circ} 36^{\prime}\right.$ $03^{\prime \prime} \mathrm{N} 114^{\circ} 32^{\prime} 46^{\prime \prime} \mathrm{E}$ ), Guangdong, south China; salinity approx. $28 \%$, water temperature approx. $25{ }^{\circ} \mathrm{C}$, approx. pH 7.8.
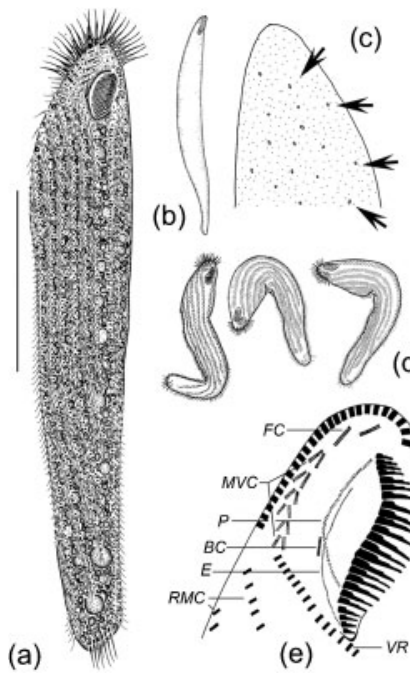

c)
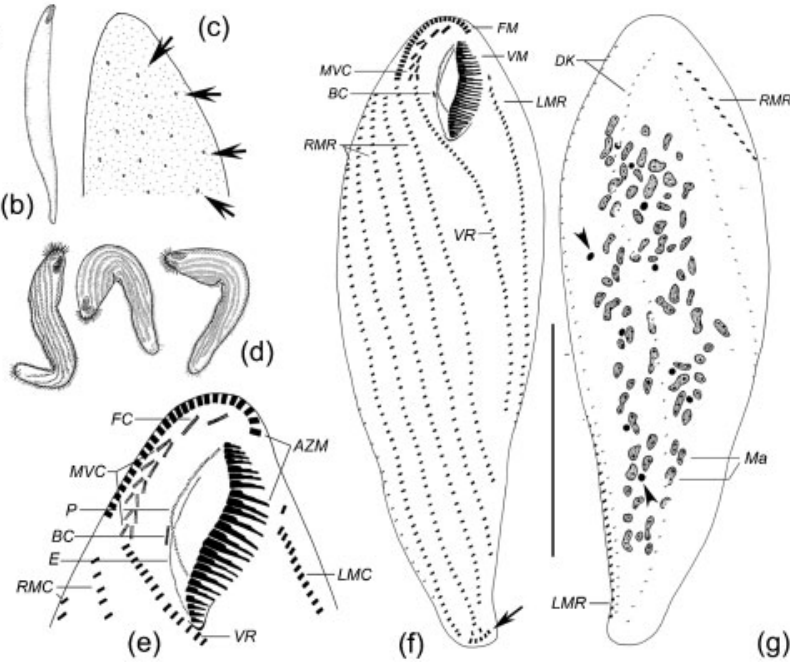

(g)
Fig. 1. Parabirojimia multinucleata spec. nov. observed in vivo $(\mathrm{a}-\mathrm{d})$ and after protargol impregnation $(e-g)$. (a) Ventral view of a typical individual. (b) Lateral view. (c) Dorsal side, showing the tiny cortical granules and the irregular-shaped larger granules (arrows). (d) Variations in cell shape illustrating the highly flexible nature of the cell. (e) Ventral infraciliature of the anterior portion of the cell. $(f, g)$ Ventral $(f)$ and dorsal $(g)$ views showing the infraciliature. Arrow in $(\mathrm{g})$ indicates the transverse cirri; arrowheads in $(\mathrm{g})$ mark the micronuclei. AZM, Adoral zone of membranelles; $B C$, buccal cirrus; DK, dorsal kineties; $E$, endoral membrane; FC, frontal cirri; FM, frontal adoral membranelles; LMC, left marginal cirri; LMR, row of left marginal cirri; Ma, macronucleus; MVC, midventral cirri; $\mathrm{P}$, paroral membrane; RMC, right marginal cirri; RMR, rows of right marginal cirri; VM, ventral adoral membranelles; VR, ventral cirral row. Bar, $100 \mu \mathrm{m}$. 


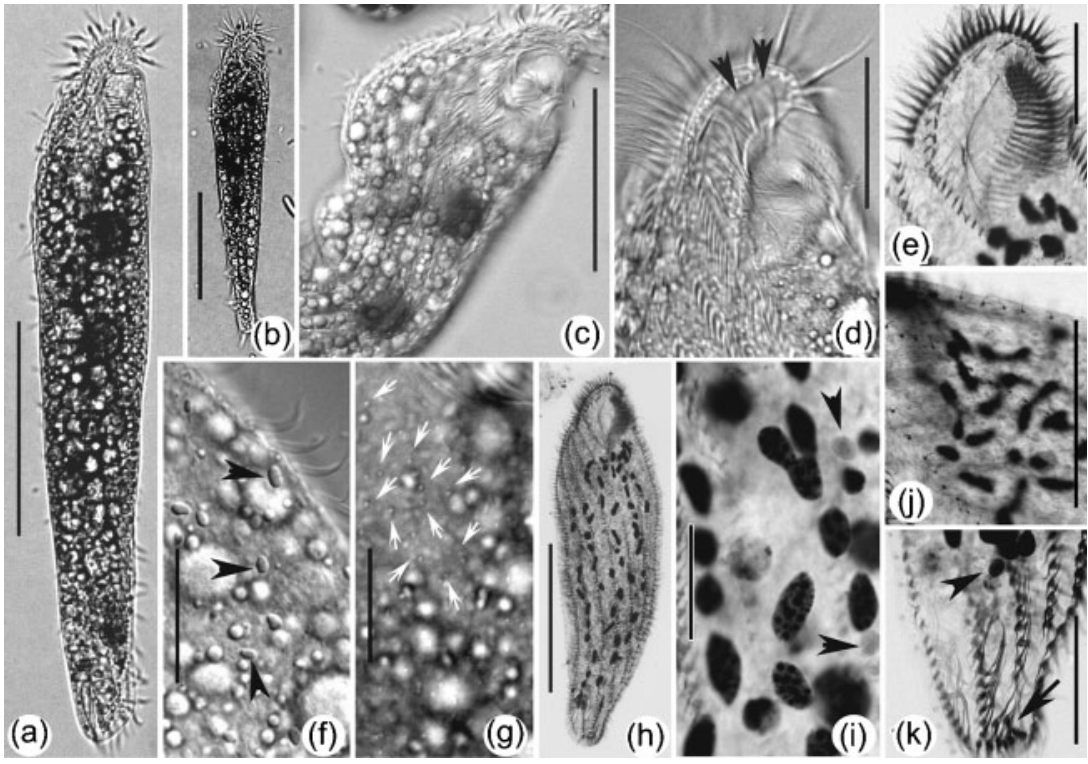

Fig. 2. Photomicrographs of Parabirojimia multinucleata spec. nov. from life $(a-d, f, g)$ and after protargol impregnation (e, h-k). (a) Ventral view of a typical individual. (b) A slender individual. (c, d) Ventral views of the anterior portion of the cell; arrowheads in (d) mark the frontal cirri. (e) Infraciliature of oral field. (f, g) Dorsal views, showing the spindleshaped granules (arrowheads in f) and the tiny cortical granules (arrows in g). (h) Ventral view to show the general infraciliature. (i) Macronuclei and micronuclei (arrowheads). (j) Dorsal kineties. (k) Posterior portion of the cell; arrow marks the transverse cirri, arrowhead depicts a micronucleus. Bars, $100 \mu \mathrm{m}(\mathrm{a}-\mathrm{c}$, h), $50 \mu \mathrm{m}(\mathrm{d}, \mathrm{e}, \mathrm{j}, \mathrm{k})$ and $10 \mu \mathrm{m}(\mathrm{f}, \mathrm{g}, \mathrm{i})$.
Type location. One holotype slide of protargol-impregnated specimens is deposited in the Laboratory of Protozoology, OUC, China, with registration number 2008:6:1:1. One paratype slide is deposited in the collection of the Natural History Museum, London, UK, with registration number $2008: 5: 13: 1$.

Description. Body slender and band-like, flexible, mostly about $300 \times 50 \mu \mathrm{m}$ in vivo, ratio of length to width 5-6:1; dorsoventrally flattened approx. 3:2 (Fig. 1b). Body widest in anterior quarter, posteriorly gradually narrowed (Figs $1 \mathrm{a}, \mathrm{d}$ and $2 \mathrm{a}, \mathrm{b}$ ). Buccal field about $10 \%$ of body length. AZM bipartite, distal end bending posteriorly onto right side, making an inconspicuous furrow along anterior-right margin.

Pellicle thin and flexible. Two types of cortical granules: type I colourless and small, approx. $0.2 \mu \mathrm{m}$ across, sparsely arranged on dorsal side (Figs $1 \mathrm{c}$ and $2 \mathrm{~g}$ ); type II spindleshaped, about $2 \times 1.5 \mu \mathrm{m}$ in size, greyish when observed at high magnification, sparsely distributed and few in number, hence never render cell any colour (Figs 1c and 2f). Cytoplasm opaque and colourless, often dark grey or even black in central part of body due to food vacuoles (8$20 \mu \mathrm{m}$ across) and other contents (Figs 1a and 2a, c), often containing numerous light-reflecting globules $(2-3 \mu \mathrm{m}$ across). About 50 macronuclear nodules, oval to elongate in shape and difficult to observe in vivo (Figs $1 \mathrm{~g}$ and $2 \mathrm{~h}, \mathrm{i}$ ). Six to 12 spherical micronuclei (Mi), each about $3 \mu \mathrm{m}$ across (Figs $1 \mathrm{~g}$ and 2i, k).

Locomotion by slow crawling without pause on debris or on bottom of Petri dish. Conspicuously flexible.

AZM with a large gap between the two parts; bases of membranelles in anterior part clearly shorter than those in posterior part (Figs 1e, f and 2e). Cilia in anterior part about $20 \mu \mathrm{m}$ long, whereas those in posterior portion are much shorter. Paroral and endoral membranes about equal in length, slightly curved and noticeably crossed (Fig. 1e, f).

All cirri relatively fine, mostly about $10 \mu \mathrm{m}$ long; each cirral base appears to be composed of two rows of basal bodies; transverse cirri about $15 \mu \mathrm{m}$ long. Invariably three slightly enlarged frontal cirri, each about $20 \mu \mathrm{m}$ long, which are continuous with the midventral cirral pairs; single buccal cirrus situated near intersection of undulating membranes (Fig. 1e, f); midventral complex composed of about five cirral pairs and one midventral row composed of 55 cirri and extending to about $65 \%$ of body length; six to 11 inconspicuous transverse cirri that project only slightly beyond posterior body margin (Figs if and $2 \mathrm{a}, \mathrm{k}$ ). One left (LMR) and five right (RMR) marginal rows; RMRs obliquely orientated from anterior right to posterior left; leftmost two or three RMRs posteriorly shortened (Fig. 1f, g). Three complete dorsal kineties, dorsal cilia about $5 \mu \mathrm{m}$ long (Figs 1g and 2j).

SSU rRNA gene sequence (Fig. 3). The GenBank/EMBL/ DDBJ accession number for the SSU rRNA gene sequence of Parabirojimia multinucleata is FJ156104 (1773 bp). It differs from that of $P$. similis in 23 sites (Fig. 3b). It grouped with $P$. similis with full support in all the methods performed (BI/ML/MP, 1.00/100/100).

\section{Remarks and comparison}

Previously, Parabirojimia was a monotypic genus, the only species being Parabirojimia similis $\mathrm{Hu}$ et al., 2002. The novel species differs from $P$. similis in having more macronuclear nodules (43-70 vs 3-6), no snout-like protrusion in the frontal field (present in P. similis), invariably five RMRs (five to eight in P. similis) and more 
Table 1. Morphometric characterization of $P$. multinucleata spec. nov. and $A$. scutellum

Data are based on protargol-stained specimens.

\begin{tabular}{|c|c|c|c|c|c|c|}
\hline Character & Species & Min. & Max. & Mean & SD & $n$ \\
\hline \multirow{2}{*}{ Body length $(\mu \mathrm{m})$} & P. multinucleata & 190 & 320 & 246.8 & 30.9 & 25 \\
\hline & A. scutellum & 55 & 70 & 60.5 & 4.4 & 12 \\
\hline Body width $(\mu \mathrm{m})$ & A. scutellum & 28 & 40 & 35.7 & 4.1 & 12 \\
\hline \multirow[t]{2}{*}{ Buccal field length $(\mu \mathrm{m})$} & P. multinucleata & 45 & 60 & 51.9 & 4.4 & 25 \\
\hline & A. scutellum & 20 & 25 & 22.3 & 1.5 & 12 \\
\hline Body length/buccal field length & A. scutellum & 2 & 3 & 2.7 & 0.2 & 12 \\
\hline \multirow[t]{2}{*}{ Adoral membranelles $(n)$} & P. multinucleata & 46 & 60 & 52.4 & 3.7 & 25 \\
\hline & A. scutellum & 17 & 18 & 17.6 & 0.5 & 12 \\
\hline \multirow[t]{2}{*}{ Buccal cirri $(n)$} & P. multinucleata & 1 & 1 & 1.0 & 0 & 25 \\
\hline & A. scutellum & 1 & 1 & 1.0 & 0 & 12 \\
\hline Frontal cirri $(n)$ & P. multinucleata & 2 & 2 & 2.0 & 0 & 25 \\
\hline Midventral cirri $(n)$ & A. scutellum & 12 & 14 & 13.0 & 0 & 12 \\
\hline \multirow[t]{2}{*}{ Transverse cirri $(n)$} & P. multinucleata & 6 & 11 & 8.3 & 1.1 & 25 \\
\hline & A. scutellum & 8 & 8 & 8.0 & 0 & 12 \\
\hline \multirow{2}{*}{ Pretransverse ventral cirri $(n)$} & P. multinucleata & - & - & - & - & - \\
\hline & A. scutellum & 2 & 2 & 2.0 & 0 & 12 \\
\hline \multirow[t]{2}{*}{ Ventral cirri $(n)$} & P. multinucleata & 44 & 69 & 58.1 & 6.1 & 25 \\
\hline & A. scutellum & - & - & - & - & - \\
\hline \multirow[t]{2}{*}{ Left marginal cirri $(n)$} & P. multinucleata & 60 & 88 & 76.7 & 6.9 & 25 \\
\hline & A. scutellum & 11 & 17 & 13.8 & 1.8 & 12 \\
\hline \multirow[t]{2}{*}{ Right marginal rows $(n)$} & P. multinucleata & 5 & 5 & 5.0 & 0 & 25 \\
\hline & A. scutellum & 1 & 1 & 1.0 & 0 & 12 \\
\hline Cirri in RMR4 $(n)$ & A. scutellum & - & - & - & - & - \\
\hline \multirow[t]{2}{*}{ Cirri in RMR5 $(n)$} & P. multinucleata & 67 & 94 & 80.7 & 6.9 & 25 \\
\hline & A. scutellum & - & - & - & - & - \\
\hline \multirow[t]{2}{*}{ Macronuclear nodules $(n)$} & P. multinucleata & 43 & 70 & 54.8 & 8.0 & 25 \\
\hline & A. scutellum & 42 & 90 & 61.7 & 15.0 & 12 \\
\hline \multirow[t]{2}{*}{ Micronuclei $(n)$} & P. multinucleata & 6 & 12 & 10.0 & 2.0 & 12 \\
\hline & A. scutellum & 2 & 2 & 2.0 & 0 & 12 \\
\hline \multirow[t]{2}{*}{ Dorsal kineties $(n)$} & P. multinucleata & 3 & 3 & 3.0 & 0 & 25 \\
\hline & A. scutellum & 3 & 3 & 3.0 & 0 & 12 \\
\hline
\end{tabular}

ventral cirri (44-69 vs 27-45), membranelles (52.4 vs 46.7 on average) and left marginal cirri (76.7 vs 61.3 on average) (Tables 1 and 2; Figs $1 \mathrm{a}, \mathrm{f}$ and $4 \mathrm{a}, \mathrm{b}$ ). In addition, $P$. multinucleata has two types of cortical granules, which are possibly absent in $P$. similis. The dissimilarity between these two forms is also supported by the molecular data, their SSU rRNA gene sequences differing by 21 substitutions and 2 indels (i.e. $1.3 \%$ ) (Fig. 3b). These findings support the validity of $P$. multinucleata as a novel species (Hu et al., 2002).

In terms of its morphology in vivo (e.g. body shape and size, number of macronuclear nodules, cell colour, etc.) and the basic pattern of its infraciliature (i.e. one left marginal row and more than one right marginal row), P. multinucleata resembles two other morphotypes, Birojimia muscorum 
Table 2. Morphological comparison of $P$. multinucleata spec. nov. with $P$. similis and some closely related morphotypes of Birojimia

Data were taken from this study (P. multinucleata), Hu et al. (2002) (P. similis), Berger \& Foissner (1989) (B. terricola) and Foissner (1982) (B. muscorum).

\begin{tabular}{|c|c|c|c|c|}
\hline Character & P. multinucleata & P. similis & B. terricola & B. muscorum \\
\hline Body length in vivo $(\mu \mathrm{m})$ & $150-350$ & $140-300$ & $135-235$ & $150-250$ \\
\hline Cortical granules & Two types, colourless & Absent & Absent & Colourless \\
\hline Adoral membranelles $(n)$ & $46-60(n=25)$ & $40-53(n=23)$ & $35-43(n=12)$ & $26-32(n=10)$ \\
\hline Buccal cirri $(n)$ & $1(n=25)$ & $1(n=25)$ & $1(n=12)$ & $1(n=10)$ \\
\hline Frontal cirri $(n)$ & $3(n=25)$ & $3(n=25)$ & $3(n=12)$ & $3(n=10)$ \\
\hline Frontoterminal cirri $(n)$ & Lacking & Lacking & $2(n=12)$ & Lacking \\
\hline Midventral cirri $(n)$ & $6-16(n=25)$ & $7-12(n=21)$ & $26(n=12)$ & $21-33(n=10)$ \\
\hline Transverse cirri $(n)$ & $6-11(n=25)$ & $3-11(n=21)$ & $4-6(n=12)$ & $2-4(n=10)$ \\
\hline Ventral cirri $(n)$ & $44-69(n=25)$ & $27-45(n=21)$ & Lacking & 7 \\
\hline Left marginal cirri $(n)$ & $60-88(n=25)$ & $50-79(n=21)$ & $40-53(n=12)$ & $34-52(n=10)$ \\
\hline Right marginal rows $(n)$ & $5(n=25)$ & $5-8(n=21)$ & $2-6(n=12)$ & $2(n=10)$ \\
\hline Caudal cirri $(n)$ & Absent & Absent & $2-7(n=12)$ & $4-7(n=10)$ \\
\hline Macronuclear nodules $(n)$ & $43-70(n=25)$ & $3-6(n=24)$ & $55-65(n=12)$ & $20-52(n=10)$ \\
\hline Dorsal kineties $(n)$ & $3(n=25)$ & $3(n=25)$ & $5(n=12)$ & $4(n=10)$ \\
\hline Habitat & Marine & Marine & Soil & Soil \\
\hline
\end{tabular}

(Kahl, 1932) Berger \& Foissner, 1989 and Birojimia terricola Berger \& Foissner, 1989. However, B. muscorum differs from P. multinucleata in habitat (soil vs marine), possession of caudal cirri (absent in P. multinucleata), having more midventral pairs (approx. 11 vs 5), midventral row composed of fewer cirri (approx. 7 vs approx. 55) and in having fewer membranelles (26-32 vs 46-60), right marginal rows ( 2 vs 5 ) and transverse cirri (2-4 vs 6-11) (Table 2)

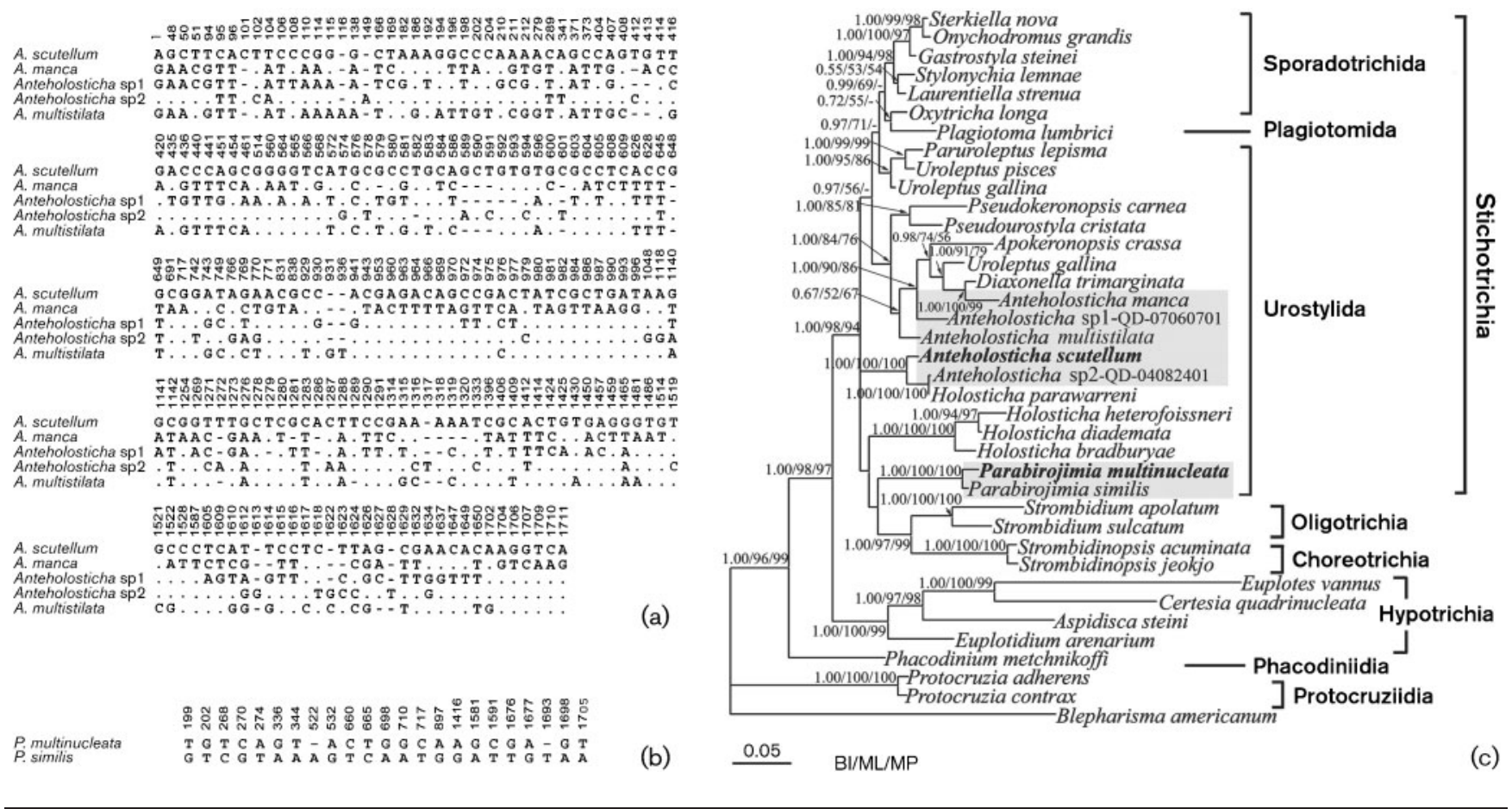

Fig. 3. $(a, b)$ Unmatched sites from SSU rRNA gene sequence alignments. Numbers represent nucleotide positions. Missing sites are indicated by dashes, and matched sites by dots. (a) Comparison of five morphologically similar Anteholosticha species. (b) Comparison of Parabirojimia multinucleata spec. nov. and P. similis. (c) Bayesian tree inferred from SSU rRNA gene sequences of stichotrich ciliates. Numbers on branches are Bayesian posterior probabilities followed by bootstrap values from ML and MP analysis. Sequences obtained in the present study are shown in bold. -, Minor differences between $\mathrm{BI}$ and other methods. 
(Kahl, 1932; Berger \& Foissner, 1989; Berger, 2006). Likewise, $P$. multinucleata differs from $B$. terricola, which usually has two to six RMR (invariably five in $P$. multinucleata), two frontoterminal cirri (frontoterminal cirri absent), two to seven caudal cirri (caudal cirri absent), no midventral row (midventral row composed of 44-69 cirri), more midventral pairs (approx. 13 vs approx. 5) and inhabits soil (marine) (Table 2) (Foissner, 1982; Berger \& Foissner, 1989).

\section{Anteholosticha scutellum (Cohn, 1866) Berger, 2003 (Fig. 5 and Tables 1 and 3)}

Syn. The detailed revision was listed by Berger (2006).

No investigations have been conducted for this species using modern methods. We therefore provide an improved diagnosis based on our observations.

Improved diagnosis. Small, oval Anteholosticha, about 50$80 \times 20-30 \mu \mathrm{m}$ in vivo; about 17 adoral membranelles; three frontal, one buccal, two frontoterminal, approx. eight transverse and two pretransverse cirri; midventral complex extends approx. $60 \%$ of cell length and comprises six or seven cirral pairs; $10-18$ right and 11-17 left marginal cirri; three dorsal kineties; about 60 macronuclear nodules; cortical granules large and scattered over dorsal side of body; marine habitat.

Slide deposition. Since no type specimens of Anteholosticha scutellum are known to exist, voucher slides of protargolimpregnated cells have been deposited in the collections of the Laboratory of Protozoology, OUC, China (registration number $2008: 6: 1: 2)$ and the Natural History Museum, London, UK (registration number 2008:5:13:2).

Description. Cell highly flexible, slightly contractile when stimulated, approx. $50-75 \times 20-30 \mu \mathrm{m}$ in vivo, outline shape usually ellipsoid, length-to-width ratio about 2 2.5:1 (Fig. 5a, f-h), dorsoventrally flattened about $3: 1$ (Fig. 5b, k). Buccal field about $25-35 \%$ of cell length.

Cortical granules (possibly extrusomes) spherical and colourless, approx. $1 \mu \mathrm{m}$ across, irregularly scattered on dorsal side (Fig. 5c, o). In protargol-stained specimens, 2$3 \mu \mathrm{m}$-long thorns were observed, having been ejected from these granules (Fig. 5e, m, n).

Cytoplasm colourless to slightly greyish, with several granules $(<2 \mu \mathrm{m})$ and numerous food vacuoles (approx. $5 \mu \mathrm{m}$ in diameter). About 60 ellipsoid macronuclear nodules, difficult to observe in vivo (Fig. 5e, l, m). Two Mi recognizable in some specimens (Fig. 5e, m).

Locomotion by crawling, medium-fast on substratum, with no peculiarities.

Infraciliature as shown in Fig. 5d. AZM evenly curved, with 17 or 18 membranelles, cilia of membranelles about $8 \mu \mathrm{m}$ long. Undulating membranes almost parallel, straight or slightly curved (Fig. 5d, 1). Three enlarged frontal cirri (FC; Fig. 5d). One buccal cirrus near anterior end of undulating membranes (BC; Fig. 5d). Two frontoterminal cirri (FTC; Fig. 5d) between distal end of AZM and anterior end of RMR (Fig. 5d). Midventral complex is composed of six or seven pairs of cirri and terminates at about the equatorial level of the cell (MVC; Fig. 5d). Eight strong transverse cirri (TC; Fig. 5d) arranged in U-shaped row; always two pretransverse ventral cirri (PTC; Fig. 5d) between transverse cirri and midventral rows. Both left and right marginal rows consist of approx. 15 cirri (Fig. 5d). DK extend whole length of body; dorsal cilia sparsely distributed, about $3 \mu \mathrm{m}$ long in vivo (Fig. 5e).

SSU rRNA gene sequence (Fig. 3a, c and Table 4). The GenBank/EMBL/DDBJ accession number for the SSU rRNA gene sequence of A. scutellum is FJ156105 (1773 bp). Regarding sequence similarity among Anteholosticha species, A. scutellum differs from A. manca by 147 nucleotides, from Anteholosticha sp1-QD-07060701 by 111 nucleotides, from $A$. multistilata by 92 nucleotides and from Anteholosticha sp2-QD-04082401 by 46 nucleotides (Fig. 3a). In the phylogenetic trees, A. scutellum forms a strongly supported clade with Anteholosticha sp2-QD04082401 and Holosticha heterofoissneri. It should be noted that the genus Anteholosticha is not monophyletic: its congeners are distributed in four clades (Fig. 3c).

\section{Remarks and comparison}

Anteholosticha scutellum was first described as Oxytricha scutellum Cohn, 1866. The original description does not include information about the cirral pattern or nuclear apparatus because, when viewed in vivo, cells are mostly opaque as a result of the blackish granules and many other cytoplasmic inclusions (Fig. 4c, d).

Kahl (1932, 1933) provided a short but significant characterization of this species (which he called Holosticha scutellum), thus: $60-120 \mu \mathrm{m}$ long in vivo, body outline usually oval, many macronuclear nodules, two conspicuous micronuclei, three slightly enlarged frontal cirri, midventral complex composed of cirral pairs, two pretransverse ventral cirri and seven or eight transverse cirri, caudal cirri absent (Fig. 4e, f). Berger (2003) redefined the genus Holosticha and transferred this species to the genus Anteholosticha, which includes forms with a continuous AZM that lack caudal cirri. In terms of living features, the organism we isolated corresponds perfectly with the descriptions of Cohn (1866) and (Kahl 1932, 1933); therefore, its identity is not in doubt.

Entz (1884) illustrated and described a form that he called Holosticha scutellum which had two ellipsoidal macronuclear nodules, each with an accompanying micronucleus, seven to 11 extremely strong transverse cirri arranged in a crescent-shaped row, two ventral cirral rows that extend from the frontal region nearly to the right transverse 


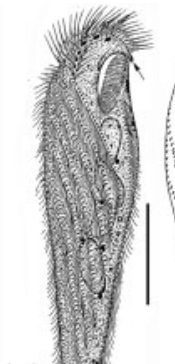

(a)

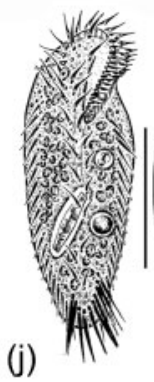

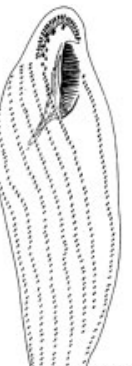

(b)

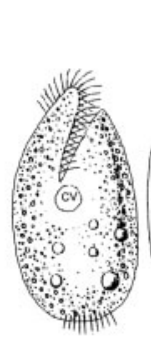

(c)

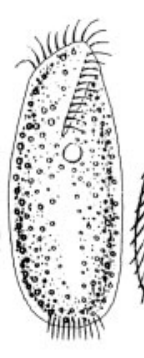

(d)

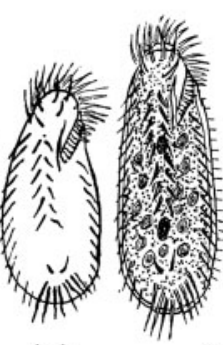

(e)

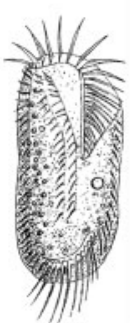

(f) (g)

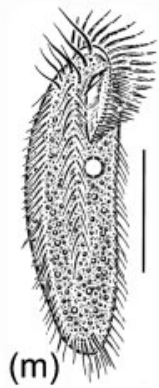

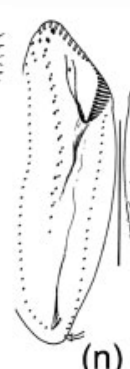

(n)

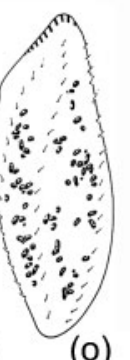

(o)

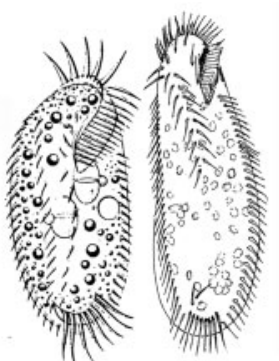

(h)

(k)

(I)

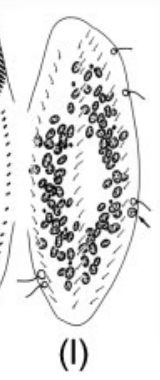

Fig. 4. Morphology of some previously reported nominal species. (a, b) P. similis (from Hu et al., 2002). (c-i) A. scutellum [c, d from Cohn (1866); e from Kahl (1933); f from Kahl (1932); g from Mansfeld (1923); h from Entz (1884); i from Borror \& Wicklow (1983)]. (j-l) A. warreni (from Song \& Wilbert, 1997a). (m-o) A. manca (from Song \& Wilbert, 1997b). (p, q) Holosticha sp. (from Wilbert \& Song, 2005). Bars, $60 \mu \mathrm{m}(\mathrm{a}, \mathrm{b}), 40 \mu \mathrm{m}(\mathrm{j}-\mathrm{l}, \mathrm{p}, \mathrm{q})$ and $50 \mu \mathrm{m}(\mathrm{m}-\mathrm{o})$.

cirri and one contractile vacuole near the left cell margin in the equatorial region of the cell (Fig. 4h). As noted by Berger (2006), this form is very similar to Holosticha diademata, so it is likely that Entz (1884) actually observed a population of this latter species rather than A. scutellum. Mansfeld (1923) also described a form under the name Holosticha scutellum with numerous macronuclear nodules and eight to ten transverse cirri arranged in a J-shaped row.

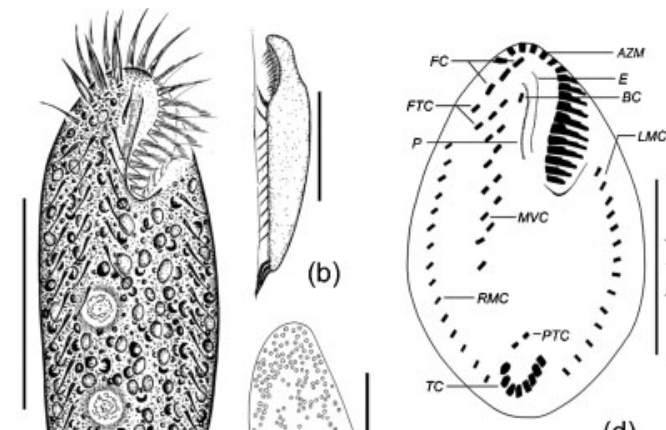

(d)

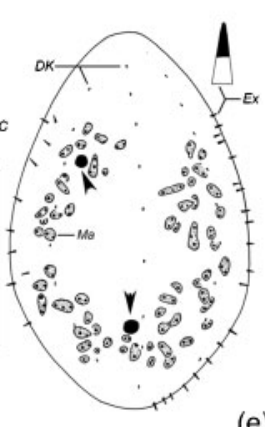

(e)

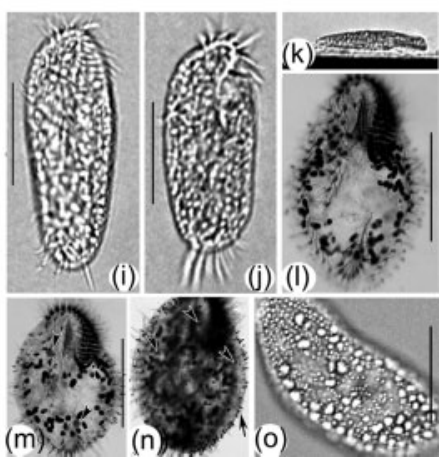

Fig. 5. Anteholosticha scutellum observed in vivo $(\mathrm{a}-\mathrm{c}, \mathrm{f}-\mathrm{k}, \mathrm{o})$ and after protargol impregnation $(d, e, I-n)$. (a) Ventral view of a typical individual. (b, k) Lateral views. (c) Dorsal view, showing the spherical cortical granules irregularly arranged. (d, e, l, m) Ventral $(\mathrm{d}, \mathrm{l}, \mathrm{m})$ and dorsal (e) views showing the infraciliature; arrowheads in (e) depict the micronuclei. $(f-j)$ Variations in body shape. (n) Dorsal view to show the dorsal kineties (arrowheads) and extrusomes (arrow). (o) Dorsal view to show the irregularly arranged spherical cortical granules. Ex, Extrusome; FTC, frontoterminal cirri; PTC, pretransverse ventral cirri; TC, transverse cirri. See Fig. 1 for other definitions. Bar, $25 \mu \mathrm{m}$. 
However, according to Mansfield's illustration, this organism has a wider AZM and more marginal cirri and midventral cirral pairs (Fig. 4g) than our population or that of Kahl $(1932,1933)$. We therefore conclude that Mansfeld (1923) observed a different form and not A. scutellum.

In terms of body size, numbers of macronuclear nodules, basic patterns of infraciliature and marine habitat, two congeners should be compared with A. scutellum: Anteholosticha warreni and A. manca (Song \& Wilbert, 1997a, b; Berger, 2003). Both are characterized by having a continuous AZM, a midventral row in a typical zigzag pattern, distinctly enlarged frontal cirri and no caudal cirri. However, A. warreni differs from A. scutellum in having more adoral membranelles (26-31 vs $17-18$ ), midventral cirri (7-9 vs 6-7), transverse cirri (approx. 11 vs approx. 8), left marginal cirri (22-27 vs approx. 14), and right marginal cirri (21-26 vs approx. 15). In addition, A. warreni has cortical granules which are approx. $2 \mu \mathrm{m}$ in size (vs approx. $1 \mu \mathrm{m})$, ellipsoid and flattened with a central depression (spherical), and arranged dorsally in three loosely organized rows (scattered randomly over the dorsal side) (Table 3; Fig. 4j-1) (Song \& Wilbert, 1997a). Borror \& Wicklow (1983) made a detailed redescription of a form they called $A$. scutellum. The specimen they illustrated, however, has about 34 adoral membranelles and about 30 right and 34 left marginal cirri (Fig. 4i). It is therefore likely that Borror \& Wicklow (1983) had observed a population of A. warreni rather than A. scutellum.

A. manca can be distinguished from A. scutellum in its body shape (fusiform vs elliptical), the arrangement of cortical granules (irregularly aligned in rows vs scattered randomly) and numbers of adoral membranelles, frontal cirri, frontoterminal cirri, midventral cirri, transverse cirri, left marginal cirri and right marginal cirri (Table 3; Fig. 4m-o) (Song \& Wilbert, 1997b).

Anteholosticha arenicola (Kahl, 1932) resembles A. scutellum in body size and shape, marine habitat and some morphometric characters (e.g. numbers of membranelles, frontal cirri, transverse cirri, left marginal cirri and right marginal cirri). However, the former can be clearly separated from the latter by having two macronuclear nodules (vs 42-90 in A. scutellum) (Table 3) (Kahl, 1932).

Wilbert \& Song (2005) described Holosticha sp. from King George Island, Antarctica. Unfortunately, only a small number of protargol-impregnated individuals were observed, and no data were collected from live observations. Nevertheless, it is likely that this form represents a population of A. scutellum, since it has the same numbers of membranelles, frontal cirri, frontoterminal cirri, buccal cirri and left marginal cirri and similar numbers of midventral cirri ( 3 or 4 vs 6 or 7 ), right marginal cirri (17 vs 15), dorsal kineties (4 vs 3 ) and macronuclear nodules (approx. 30 vs approx. 60) (Table 3; Fig. 4p-q) (Berger, 2006; Wilbert \& Song, 2005).

\section{Molecular comparison with congeners}

The separation of A. scutellum from A. manca, Anteholosticha sp1 QD-07060701, Anteholosticha sp1 QD04082401 and A. multistilata is supported by differences in their SSU rRNA gene sequences and its unambiguous

Table 3. Morphological comparison of Anteholosticha scutellum with some related species

Data were taken from this study (A. scutellum), Song \& Wilbert (1997a) (A. warreni), Song \& Wilbert (1997b) (A. manca), Kahl (1932) (A. arenicola) and Wilbert \& Song (2005) (Holosticha sp.). NA, Data not available. All species are marine.

\begin{tabular}{|c|c|c|c|c|c|}
\hline Character & A. scutellum & A. warreni & A. manca & A. arenicola & Holosticha sp. \\
\hline Body shape & $\begin{array}{l}\text { Elliptical, both ends } \\
\text { rounded }\end{array}$ & $\begin{array}{c}\text { Elliptical, both ends } \\
\text { narrowly rounded }\end{array}$ & $\begin{array}{l}\text { Fusiform, both ends } \\
\text { rounded }\end{array}$ & $\begin{array}{c}\text { Symmetrical } \\
\text { ovoid }\end{array}$ & $\mathrm{NA}$ \\
\hline Cortical granules & Scattered, $\sim 1 \mu \mathrm{m}$ & $\begin{array}{l}\text { Erythrocyte in shape, } \\
\qquad 2 \mu \mathrm{m}\end{array}$ & $\begin{array}{c}\text { Irregularly aligned in } \\
\text { rows, } \sim 1 \mu \mathrm{m}\end{array}$ & NA & $\mathrm{NA}$ \\
\hline Adoral membranelles $(n)$ & $17-18(n=12)$ & $26-31(n=16)$ & $21-27(n=11)$ & $23 \dagger$ & $\sim 17$ \\
\hline Frontal cirri $(n)$ & $3(n=12)$ & $3(n=30)$ & $4(n=16)$ & 3 & 3 \\
\hline Frontoterminal cirri $(n)$ & $2(n=12)$ & $2(n=30)$ & $2-4(n=16)$ & NA & 2 \\
\hline Midventral cirrus pairs $(n)$ & $6-7(n=12)$ & $7-9(n=11)$ & $9-16(n=11)$ & $10 \dagger$ & $\sim 3$ or 4 \\
\hline Transverse cirri $(n)$ & $\sim 8(n=12)$ & $\sim 11(n=16)$ & $4-6(n=16)$ & $7-10 \dagger$ & $6-7$ \\
\hline Left marginal cirri $(n)$ & $\sim 14(n=12)$ & $22-27(n=16)$ & $22-29(n=11)$ & $11 \dagger$ & 14 \\
\hline Right marginal cirri $(n)$ & $\sim 15(n=12)$ & $21-26(n=16)$ & $6-34(n=11)$ & $13 \dagger$ & 17 \\
\hline
\end{tabular}

${ }^{\star}$ Data from protargol-impregnated specimens.

$\dagger$ Determined from illustration. 
Table 4. SSU rRNA gene sequence similarity (\%) among $A$. scutellum and four congeners

\begin{tabular}{|c|c|c|c|c|c|}
\hline Species & 1 & 2 & 3 & 4 & 5 \\
\hline 1. A. scutellum & $(100)$ & & & & \\
\hline 2. A. manca & 91.4 & (100) & & & \\
\hline $\begin{array}{l}\text { 3. Anteholosticha sp1-QD- } \\
04082401\end{array}$ & 93.4 & 94.1 & (100) & & \\
\hline $\begin{array}{l}\text { 4. Anteholosticha sp2-QD- } \\
07060701\end{array}$ & 97.3 & 90.7 & 90.9 & $(100)$ & \\
\hline 5. A. multistilata & 94.5 & 91.2 & 95.6 & 91.2 & $(100)$ \\
\hline
\end{tabular}

position in the phylogenetic trees (Fig. 3a, c). Pairwise sequence similarities between A. scutellum and its congeners range from 91.4 to $97.3 \%$ (Table 4), i.e. the differences range from 2.7 to $8.6 \%$. Such molecular differences, combined with its unique morphological and morphogenetic features, support the conclusion that $A$. scutellum is a well-outlined and distinctive member of the genus Anteholosticha.

Berger (2003) split Anteholosticha from Holosticha based on the absence of several Holosticha apomorphies and caudal cirri, and also predicted the heterogeneity of Anteholosticha. In the present and previous studies, SSU rRNA gene trees have supported the clear separation of Holosticha and Anteholosticha. Meanwhile, consistent with the hypothesis of Berger (2003) and previous molecular studies (Schmidt et al., 2007, Yi et al., 2008), Anteholosticha is recovered as a conspicuously divergent group, with its congeners distributed in four separate clades.

\section{ACKNOWLEDGEMENTS}

This work was supported by the Natural Science Foundation of China (project nos 30870264; 30700069), the Center of Excellence in Biodiversity, King Saud University, and the Darwin Initiative (project no. 14-015), which is funded by the UK Department for Environment, Food and Rural Affairs.

\section{REFERENCES}

Berger, H. (2003). Redefinition of Holosticha Wrzesniowski, 1877 (Ciliophora, Hypotricha). Eur J Protistol 39, 373-379.

Berger, H. (2004). Uroleptopsis Kahl, 1932 (Ciliophora, Hypotricha): morphology and cell division of type species, redefinition, and phylogenetic relationships. Acta Protozool 43, 99-122.

Berger, H. (2006). Monograph of the Urostyloidea (Ciliophora, Hypotricha). Monogr Biol 85, 1-1304.

Berger, H. \& Foissner, W. (1989). Morphology and biometry of some soil hypotrichs (Protozoa, Ciliophora) from Europe and Japan. Bull Br Mus Nat Hist (Zool) 55, 19-46.

Borror, A. C. \& Wicklow, B. J. (1983). The suborder Urostylina Jankowski (Ciliophora, Hypotrichida): morphology, systematics and identification of species. Acta Protozool 22, 97-126.

Cohn, F. (1866). Neue Infusorien im Seeaquarium. Z Wiss Zool Leipzig 16, 253-302 (in German).
Corliss, J. O. (1979). The Ciliated Protozoa: Characterization, Classification and Guide to the Literature, 2nd edn. Oxford: Pergamon Press.

Entz, G. (1884). Über Infusorien des Golfes von Neapel. Mitt Zool Stn Neapel 5, 289-444 (in German).

Foissner, W. (1982). Ökologie und Taxonomie der Hypotrichida (Protozoa: Ciliophora) eineger österreichischer Böden. Arch Protistenkd 126, 19-143 (in German).

Gao, S., Chen, Z., Shao, C., Long, H., Al-Rasheid, K. A. S. \& Song, W. (2008). Reconsideration of the phylogenetic position of Frontoniarelated Peniculia (Ciliophora, Protozoa) inferred from the small subunit ribosomal RNA gene sequences. Acta Protozool 47, 47-54.

Gong, J., Kim, S., Kim, S., Min, G., Roberts, D., Warren, A. \& Choi, J. (2007). Taxonomic redescriptions of two ciliates, Protogastrostyla pulchra n. g., n. comb. and Hemigastrostyla enigmatica (Ciliophora: Spirotrichea, Stichotrichia), with phylogenetic analyses based on $18 \mathrm{~S}$ and $28 \mathrm{~S}$ rRNA gene sequences. J Eukaryot Microbiol 54, 468-478.

Guindon, S. \& Gascuel, O. (2003). A simple, fast and accurate algorithm to estimate large phylogenies by maximum likelihood. Syst Biol 52, 696-704.

$\mathrm{Hu}, \mathrm{X}$. (2008). Cortical structure in non-dividing and dividing Diophrys japonica spec. nov. (Ciliophora, Euplotida) with notes on morphological variation. Eur J Protistol 44, 115-129.

Hu, X., Song, W. \& Warren, A. (2002). Observations on the morphology and morphogenesis of a new marine urostylid ciliate, Parabirojimia similis nov. gen., nov. spec. (Protozoa, Ciliophora, Hypotrichida). Eur J Protistol 38, 351-364.

Kahl, A. (1932). Urtiere oder Protozoa I: Wimpertiere oder Ciliata (Infusoria) 3. Spirotricha. In Die Tierwelt Deutschlands und der angrenzenden Meeresteile, vol. 25, pp. 399-650. Jena: Gustav Fischer (in German).

Kahl, A. (1933). Ciliata libera et ectocommensalia. In Die Tierwelt der Nord- und Ostsee, vol. 23, pp. 29-146. Edited by G. Grimpe \& E. Wagler. Leipzig: Akademische Verlagsgesellschaft (in German).

Li, L., Song, W., Warren, A., Al-Rasheid, K. A. S., Roberts, D., Yi, Z., Al-Farraj, S. A. \& Hu, H. (2008). Morphology and morphogenesis of a new marine ciliate, Apokeronopsis bergeri nov. spec. (Ciliophora, Hypotrichida) from the Yellow Sea, China. Eur J Protistol 44, 208-219.

Lin, X., Song, W. \& Li, J. (2007). Amphileptus aeschtae nov. spec. and Amphileptus eigneri nov. spec. (Ciliophora, Pleurostomatida), two new marine pleurostomatid ciliates from China. Eur J Protistol 43, $77-86$.

Lin, X., Li, J., Gong, J., Warren, A. \& Song, W. (2008). Taxonomic studies on three marine pleurostomatid ciliates, Litonotus bergeri nov. spec., L. blattereri nov. spec. and L. petzi nov. spec. (Ciliophora, Pleurostomatida) from North China Sea. Eur J Protistol 44, 91-102.

Lynn, D. H. \& Small, E. B. (2002). Phylum Ciliophora Doflein, 1901. In An Illustrated Guide to the Protozoa, 2nd edn, pp. 371-656. Edited by J. J. Lee, G. F. Leedale \& P. C. Bradbury. Lawrence, KS: Society of Protozoologists.

Mansfeld, K. (1923). 16 neue oder wenig bekannte marine Infusorien. Arch Protistenkd 46, 97-140 (in German).

Nylander, J. A. A. (2004). Mr Modeltest 2. Uppsala: Evolutionary Biology Centre, Uppsala University.

Ronquist, F. \& Huelsenbeck, J. P. (2003). MrBayes 3: Bayesian phylogenetic inference under mixed models. Bioinformatics 19, 15721574.

Schmidt, S., Bernhard, D., Schlegel, M. \& Foissner, W. (2007). Phylogeny of Stichotrichia (Ciliophora; Spirotrichea) reconstucted with nuclear small subunit rRNA gene sequences: discrepancies and 
accordances with morphological data. J Eukaryot Microbiol 54, 201-209.

Shao, C., Miao, M., Song, W., Warren, A., Al-Rasheid, K. A. S., Al-Quaishy, S. A. \& Al-Farraj, S. A. (2008a). Studies on two marine Metaurostylopsis spp. from China with notes on the morphogenesis of M. sinica nov. spec. (Ciliophora, Urostylida). Acta Protozool 47, 95-112.

Shao, C., Song, W., Al-Rasheid, K. A. S., Yi, Z., Al-Farraj, S. A. \& Al-Quraisy, S. A. (2008b). Morphology and infraciliature of two new marine urostylid ciliates: Metaurostylopsis struederkypkeae nov. spec. and Thigmokeronopsis stoecki nov. spec. (Ciliophora, Hypotrichida) from China. J Eukaryot Microbiol 55, 289-296.

Song, W. \& Wilbert, N. (1997a). Morphological studies on some free living ciliates (Ciliophora: Heterotrichida, Hypotrichida) from marine biotopes in Qingdao, China, with descriptions of three new species: Holosticha warreni nov. spec., Tachysoma ovata nov. spec. and T. dragescoi nov. spec. Eur J Protistol 33, 48-62.
Song, W. \& Wilbert, N. (1997b). Morphological investigations on some free living ciliates (Protozoa, Ciliophora) from China Sea with description of a new hypotrichous genus, Hemigastrostyla nov. gen. Arch Protistenkd 148, 413-444.

Swofford, D. L. (2002). PAUP*. Phylogenetic analysis using parsimony (* and other methods). Sunderland, MA: Sinauer Associates.

Wilbert, N. (1975). Eine verbesserte Technik der Protargolimprägnation für Ciliaten. Mikrokosmos 64, 171-179 (in German).

Wilbert, N. \& Song, W. (2005). New contributions to the marine benthic ciliates from the Antarctic area, including description of seven new species (Protozoa, Ciliophora). J Nat Hist 39, 935-973.

Yi, Z., Song, W., Warren, A., Roberts, D. M., Al-Rasheid, K. A. S., Chen, Z., Al-Farraj, S. A. \& Hu, X. (2008). A molecular phylogenetic investigation of Pseudoamphisiella and Parabirojimia (Protozoa, Ciliophora, Spirotrichea), two genera with ambiguous systematic positions. Eur J Protistol 44, 45-53. 